\title{
TRADITIONAL AGRICULTURAL LANDSCAPE AND THEIR MANAGEMENT IN LESS FAVOURED AREAS IN SLOVAKIA
}

\author{
JANA ŠPULEROVÁ ${ }^{1}$, MONIKA DRÁBOVÁ ${ }^{2}$, JURAJ LIESKOVSKÝ ${ }^{3}$ \\ ${ }^{1}$ Institute of Landscape Ecology of the Slovak Academy of Sciences, P.O.Box 254, Štefánikova 3, 81499 Bratislava, \\ Slovak Republic; e-mail: jana.spulerova@savba.sk \\ ${ }^{2}$ Constantine the Philosopher University in Nitra, Faculty of Natural Sciences, Department of Ecology and Environ- \\ ment, Trieda A. Hlinku 1, 949 74, Nitra, Slovak Republic; e-mail: monika.drabova@savba.sk \\ ${ }^{3}$ Institute of Landscape Ecology of the Slovak Academy of Sciences, branch Nitra, Akademická 2, 94901 Nitra, Slo- \\ vak Republic; e-mail: juraj.lieskovsky@savba.sk
}

\begin{abstract}
Špulerová J., Drábová M., Lieskovský J.: Traditional agricultural landscape and their management in less favoured areas in Slovakia. Ekológia (Bratislava), Vol. 35, No. 1, p. 1-12, 2016.

Traditional agricultural landscapes are a mosaic of small-scale arable fields and permanent agricultural cultivations such as grasslands, vineyards and high-trunk orchards. Most of them are threatened by abandonment as they are usually situated in marginal mountain regions with less favourable conditions for agriculture. Our aim was to analyse the distribution of traditional agricultural landscapes in less favoured areas and the effects of the supportive measures of the Common Agricultural Policy, which are oriented towards helping farmers from these areas in maintaining traditional agriculture. Except for traditional agricultural vineyard landscapes, almost all TAL plots are situated in less favoured areas. Most of them are located in mountain areas with less favourable conditions for agriculture. Abandonment of traditional agricultural landscape inside the less favoured areas is significantly higher than in locations elsewhere. The supportive measures of the Common Agricultural Policy do not effectively mitigate this abandonment. If we would like to maintain traditional agricultural landscape in less favoured areas, it is necessary to stop the existing negative trend of abandonment and search for new ways to motivate farmers to continue their traditional farming by adjusting the conditions of the common agricultural policy to benefit small farmers as well.
\end{abstract}

Key words: less favoured areas, abandonment, management intensity, Common Agriculture Policy.

\section{Introduction}

The European Union has been supporting less favoured areas (LFA) as part of the Common Agricultural Policy (CAP) since 1975 (Dax, 2005). The objective of this is to maintain agricultural production in areas where management without external support would be economically disadvantaged, and also to take environmental considerations into account in LFA-related financial instruments (Rudow, 2014).

LFAs are defined in terms of a fragile agricultural resource base and/or limited access to markets and infrastructure (Pender, Hazell, 2000). LFAs thus face resource constraints occa- 
sioned either by nature or by man (Ruben, Pender, 2004). From the agro-ecological point of view, they are areas with a limited agricultural potential due to low or uncertain rainfall, poor soils, steep slopes or other biophysical constraints. Socio-economic constraints are prevalent in these territories that face limited access to markets due to scarcity of infrastructure and other related limitations (i.e. poor service provision).

Exact LFA definitions are drawn up by national authorities in accordance with European Union regulations (Council Regulation No. 1257/1999, EU/EC 86/466/EEC, 1986). As a result of a large number of implementing directives, LFA in the member states of the EU is currently classified into three types, discussed below (Dax, 2005). Each category includes several types of handicaps common to certain areas of agricultural land across Europe, which threatens the continuation of agricultural land use. Slovakia has followed up on these requirements for support of LFA management by passing Government Regulation No. 499/2008 Coll. The LFA definitions were drawn up with respect to natural, economic and demographic conditions (Ministry of Agriculture, 2008). The three basic types of LFA were defined: (1) mountain areas; (2) other less-favoured areas and (3) areas affected by specific handicaps.

This contribution analyses the role of LFA in maintenance of traditional agricultural landscapes (TAL) in Slovakia. TAL are mosaics of small-scale arable fields and permanent agricultural cultivations such as grasslands, vineyards and high-trunk orchards. They originated as a result of a long-term mutual relationship between man and the landscape and they depend on continuous agricultural activity. The majority of TAL in Slovakia was destroyed during the collectivisation of agriculture (Lieskovský et al., 2014) and only small fragments have survived till today. Currently, they are threatened by abandonment as they are usually situated in marginal mountain regions with difficult climatic conditions, steep slopes or low soil productivity (Lieskovský et al., 2015; Mojses, Petrovič, 2013). Even though they are valuable from a biodiversity and cultural/historical points of view (Baránková et al., 2011; Dankaninová, Gajdoš, 2012; Machová, Kubát, 2014; Špulerová et al., 2014), they rarely attract attention in discussion of conservation of cultural heritage or the natural environment. TAL are seriously threatened by the irreversible decline (and associated loss of biodiversity) of these specific forms of land use in the near future (Dobrovodská, 2006; Slámová et al., 2013).

Assuming that the majority of the TAL are located in LFA areas, we decided to focus on LFA support as one of the possibilities for TAL maintenance. Therefore, the aims of our study were:

1. to analyse the distribution of TAL in LFA and explain how it is affected by natural and socio-economic conditions in the LFA and

2. to compare the management of TAL located within and outside the LFA areas, and evaluate the effectiveness of supportive measures of the CAP in assisting LFA farmers with TAL maintenance.

\section{Methods and study area}

Study area

Agricultural land occupies almost $50 \%$ of the territory of Slovakia and consists mostly of large-scale fields that originated during the collectivisation of agriculture (1950s-1970s). This state of affairs results from optimum conditions for plant and animal production and from social-political development as well. The settlement in the lowlands of 
Slovakia by Slovenians occurred in the 9th to 11th centuries, while colonisation of the mountain areas occurred later in two main phases: (1) German colonisation (13th and 14th centuries) and (2) Walachian colonisation (from 16th to 18 th centuries). These movements and the resulting settlement structures were largely determined by the layout and natural conditions of the land. The most accessible areas and most fertile soils were populated first. Later, when most of the fertile soils were under cultivation, mountain and borderland regions were settled and colonised. The result was a cultural mosaic of a landscape characterised by high biodiversity due to the heterogeneity of land forms and cover, relief segmentation and variety of farming products. Remnants of this landscape have been preserved only in less accessible and less fertile localities, as a large part of the landscape was transformed by government intervention and intensification of agriculture in the second half of the 20th century. Fragments of traditionally managed agricultural landscapes now constitute only $0.9 \%$ of the entire area of Slovakia (Špulerová et al., 2011). After the change to a market-oriented economy in 1989, management of these valuable structures decreased rapidly. Recent developments in the Common Agricultural Policy have focused on maintenance of intensive large-scale farming rather than direct enhancement of agro-biodiversity, even though support for less favoured areas is included in the CAP (Bezák, Mitchley, 2014).

\section{Traditional agricultural landscapes data}

We used the data from the nationwide mapping of TAL that was performed in the years 2009-2011 (Dobrovodská et al., 2010; Špulerová et al., 2011). The TAL polygons were delineated by interpretation of aerial photos and historical maps from the pre-collectivisation era. 3,013 TAL plots were mapped in total, with a total area of 44,464 ha (Špulerová et al., 2011). To get a more detailed overview of the different varieties of TAL, we adopted the classification based on land use categories according to Špulerová et al. (2011): (I) TAL with dispersed settlements, (II) TAL of vineyards, (III) TAL of arable-land, grasslands and orchards, and (IV) TAL of arable-land and grasslands.

Information about management intensity was gleaned from the proportion of managed plots within the TAL polygons (Lieskovský et al., 2015). Three categories were distinguished: (1) areas with more than 70\% of regularly managed plots; (2) partly abandoned mosaics with 30 to $70 \%$ managed plots; (3) mostly abandoned mosaics with less than $30 \%$ of plots managed.

\section{Less favoured areas data}

The map of LFA was provided by the Ministry of Agriculture (Ministry of Agriculture, 2009), which defines three types of LFA according to the type of handicap in Slovakia:

1. Mountain areas include municipalities that meet one of the following criteria:

(1) The average altitude of the municipality is greater than or equal to 700 m.a.s.l.

(2) Average altitude of the municipality is greater than or equal to 600 m.a.s.l. and less than 700 m.a.s.l.

(3) The slope rate of the municipality is greater than or equal to $20 \%\left(11.18^{\circ}\right)$ over more than $50 \%$ of the area of the municipality.

(4) The average altitude of the municipality is greater than or equal to 500 m.a.s.l and less than 600 m.a.s.l. and the slope rate is more than $15 \%\left(8.31^{\circ}\right)$ over more than $50 \%$ of the area of the municipality.

2. Other less-favoured areas are integrated territories meeting the economic criteria: (1) Low values of the agricultural productivity of the land.

(2) Permanent grasslands and forage covers at least $50 \%$ of the area.

(3) Grain yield is less than $80 \%$ of the national average.

(4) Low values of specific indicators such as the number of livestock, population density and the proportion of agricultural workers in the economically active population in the district.

3. Areas affected by specific handicaps include the cadastral areas of municipalities whose territories have:

(1) waterlogged soil of area $50 \%$ or more that of the agricultural land;

(2) extremely dry soil of area $50 \%$ or more that of the agricultural land;

(3) skeletal soils of area $50 \%$ or more that of the agricultural land;

(4) Flysch zone soils;

(5) less productive soils; and

(6) transition area soils.

The aid to farmers in LFA provides a mechanism for maintaining the countryside in areas where agricultural production or activity is more difficult because of natural handicaps. Funding is used to avoid the risk of land aban- 


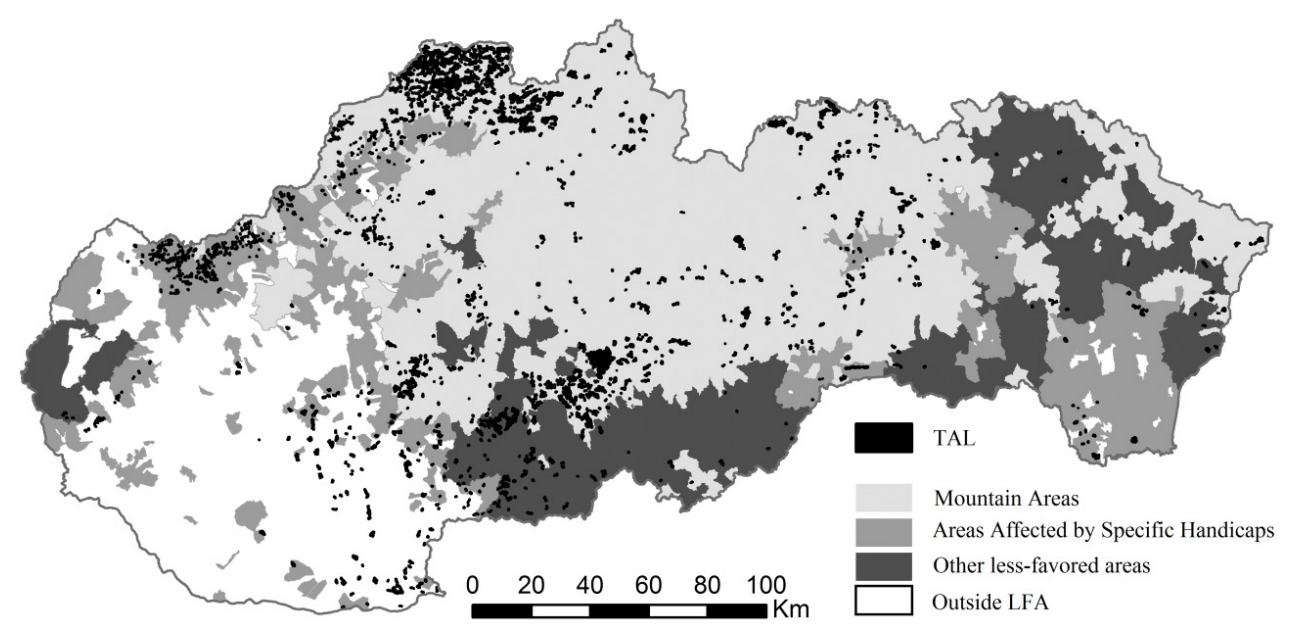

Fig. 1. Distribution of traditional agricultural landscape (Špulerová et al., 2011) within Less Favoured Areas in Slovakia (Ministry of Agriculture, 2009).

donment and to help maintain the countryside by ensuring continued agricultural land use. LFA beneficiaries are required to undertake to farm for at least five years from the first payment and to farm a minimum area of 1 ha of eligible land. The amount of payments for each LFA is differentiated by farming systems implemented separately for arable land and for grasslands on which the minimum stocking density is 0,3 grazing livestock per ha.

\section{Data analysis}

The analysis of the TAL distribution within the LFA was done by synthesis of TAL and LFA maps with analysis of the natural conditions and socioeconomic situation of TAL polygons.

As a first step, we overlaid the TAL map with the LFA areas and summed up the areas of the four TAL types within different LFA areas. We used the union tool in the ArcGIS 10.1 analysis toolbox for this.

In the second step, we analysed the natural and socio-economic conditions of TAL (elevation, slope steepness, soil production, grain yield data and demographic data) using the spatial statistics method. Elevation and slope steepness were evaluated from a digital elevation model derived from a civil contour map at 1:10,000 scale. Soil production potential was calculated as a function of grain size distribution and soil type following the methods of Džatko (2003). For that, we used interpolated data from soil samples combined with forest soil maps. Grain yield data were taken from the DATAcube database of Statistical Office of the Slovak Republic. Demographic data were available from the 2010 census.

As the purpose of LFA payments is to compensate for lower agricultural production on low-production areas and to mitigate the abandonment of highly valuable rural landscape, we assume that if the payments are effective, the intensity of management of TAL outside and inside the LFA will be similar. Therefore, our null hypothesis is that the LFA payments compensate for lower agricultural production and the proportions of managed and abandoned TAL are the same both outside and inside LFA. Our alternative hypothesis is that if LFA support is not effective, the proportion of managed TAL inside LFA will be significantly lower than the proportion of managed TAL outside LFA, and thus the proportion of abandoned TAL inside LFA significantly higher than the proportion of abandoned TAL outside LFA. We tested these hypotheses with a one-tailed Z-test of population proportions. To incorporate the effect of the different sizes of TAL polygons, we calculate the proportions with respect to TAL area, not to the number of polygons. 


\section{Results}

\section{Distribution of Traditional Agricultural Landscapes in Less Favoured Areas}

Our analysis of TAL classes and their representation within the three LFA types (Fig. 1 and Table 1) showed that $90.54 \%$ of TAL are located in LFA areas. Of these, $78.99 \%$ belong to mountain areas, $10.99 \%$ to areas affected by specific handicaps and $10.02 \%$ to other less favoured areas.

The percentage of TAL types located in different types of LFA is depicted in Fig. 2. The majority of all TAL types are located in LFA areas. The exception is the TAL of vineyards, which is mostly located in the warmer lowland regions of southern Slovakia, outside of the LFA. The other three types of TAL are mostly concentrated in mountain LFA. This type of LFA covers the largest area, so almost half of the TAL is located there.

Other less favoured areas - those with poor productivity land, low productivity of the natural environment and a low or dwindling population predominantly dependent on agricultural activity - constitute about $10 \%$ of each TAL class. A slightly higher percentage of TAL are present in areas affected by specific handicaps such as water-logged soils, extreme dry soils, skeletal soil areas, flysch soil areas, low productive soil areas and intermediary soil areas.

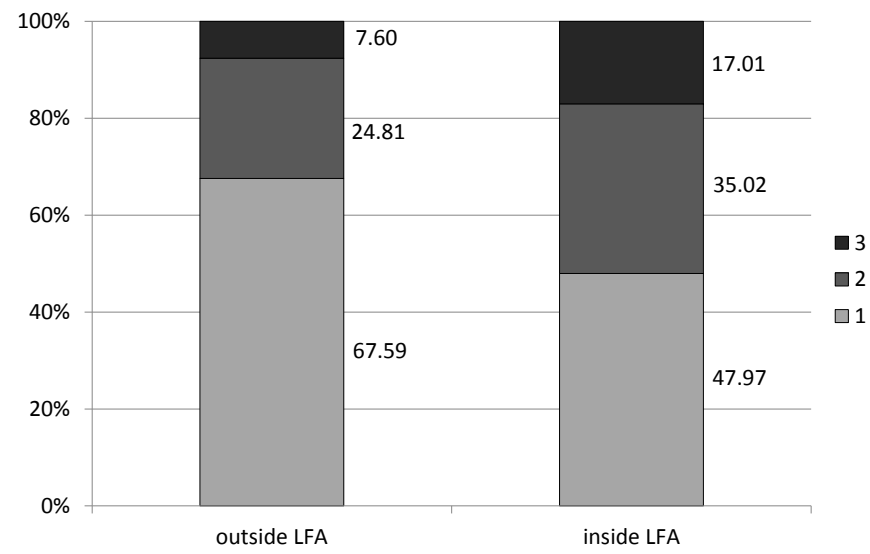

Fig. 2. Management of Traditional Agricultural Landscapes within and outside the Less Favoured Areas. Management intensity degree: (1) managed; (2) partly abandoned (3) abandoned.

T a b l e 1. Breakdown of TAL classes by Less Favoured Areas types.

\begin{tabular}{lccccccc}
\hline & & I. & II. & III. & IV. & $\begin{array}{c}\text { Total TAL } \\
\text { in area }\end{array}$ & LFA Area \\
\hline $\begin{array}{l}\text { Mountain Areas } \\
\text { Areas Affected by Specific }\end{array}$ & ha & 17023.2 & 202.1 & 1267.4 & 13269.5 & 31762.2 & 2222772.2 \\
$\begin{array}{l}\text { Handicaps } \\
\text { ha }\end{array}$ & 1776.0 & 2191.8 & 402.8 & 97.7 & 4468.3 & 762272.7 \\
Outher Less Favoured Areas & ha & 2292.6 & 1151.7 & 180.8 & 405.7 & 4030.8 & 886311.4 \\
Sum/Total area & ha & 5.3 & 4156.3 & 32.5 & 8.8 & 4202.9 & 1030970.9 \\
\hline
\end{tabular}

Classes of Traditional Agricultural Landscapes: (I) TAL with Dispersed Settlements; (II) TAL of Vineyards; (III) TAL of Arable-Land, Grasslands and Orchards; (IV) TAL of Arable-Land and Grasslands. 

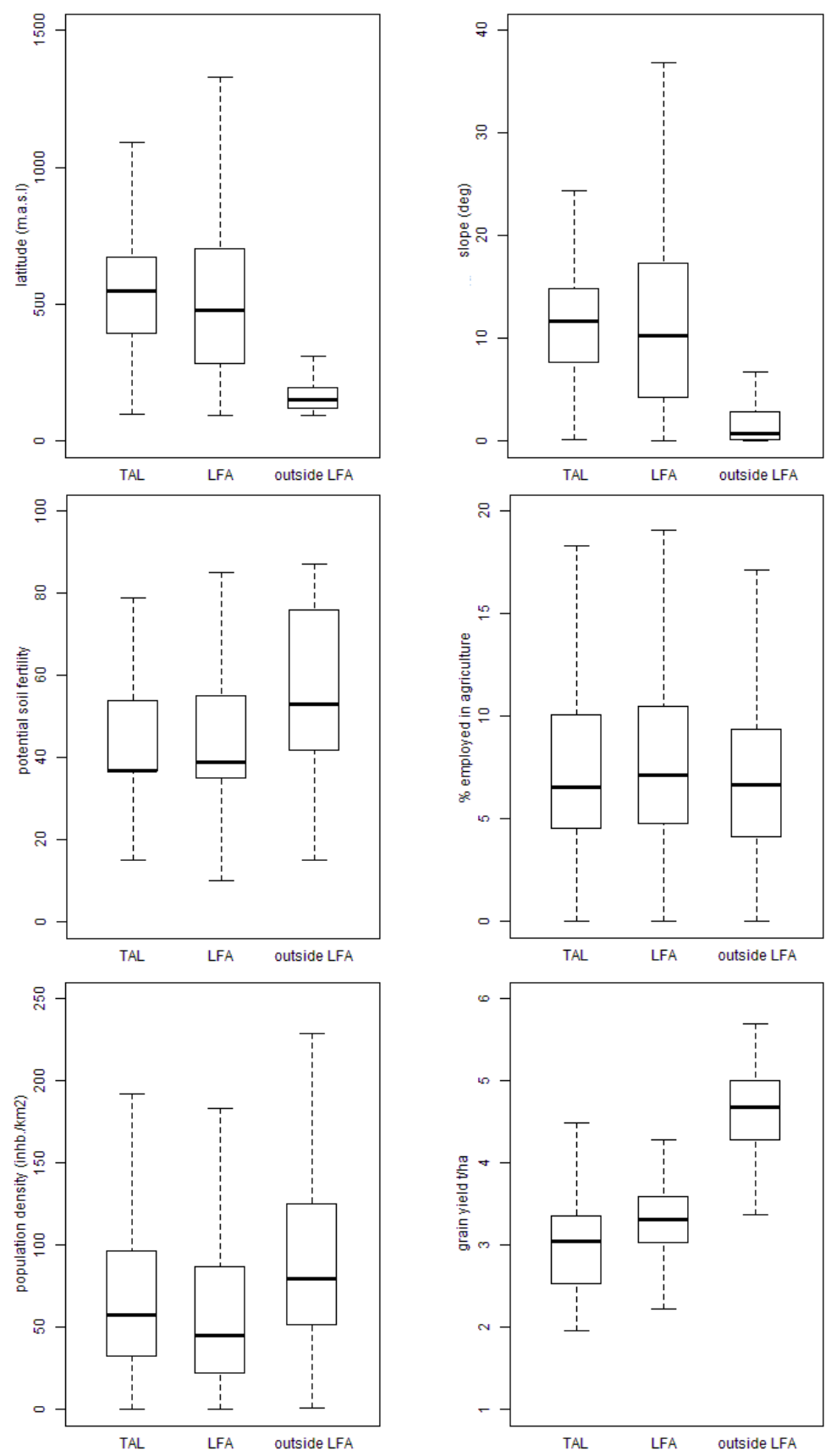

Fig. 3. Distribution of Traditional Agricultural Landscapes and Less Favoured Areas by geographical factors related to handicap indicators for Less Favoured Areas, showing minimum, maximum, standard deviation and mean average of plotted parameters. 


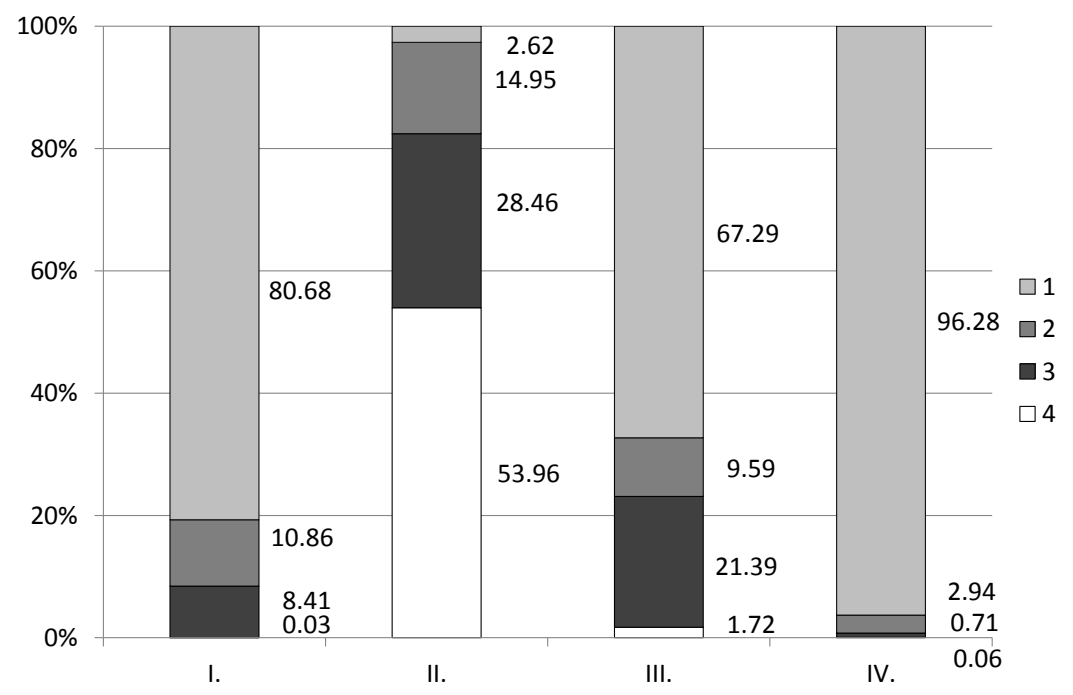

Fig. 4. Percentage share of TAL classes in different LFA types.

Classes of Traditional Agricultural Landscapes: (I) TAL with Dispersed Settlements; (II) TAL of Vineyards; (III) TAL of Arable-Land, Grasslands and Orchards; (IV) TAL of Arable-Land and Grasslands. Less Favoured areas: 1 - Mountain Areas, 2 - Areas Affected by Specific Handicaps, 3 - Other Less Favoured Areas, 4 - Outside LFA.

Spatial statistics regarding the natural and socioeconomic conditions of TAL - which we compiled for TAL overall, and TAL both outside and inside LFA - show us that the environmental conditions of TAL in LFA are virtually the same as the conditions on which most of the TAL are located (Fig. 3). Most of the TAL plots are situated at altitudes greater than 500 m.a.s.l., and they have a mean slope of $11.46^{\circ}$, characteristic of mountain areas of LFA.

Mean grain yield in TAL areas is less than minimum value of grain yield outside LFA, meeting one of the 'other LFA' criteria. Another criterion is met by population density, of which the mean overall value in both TAL and LFA areas is between 86.88 and 88.38 inhabitants $/ \mathrm{km}^{2}$, while the mean value of non-LFA areas is 127,99 inhabitants $/ \mathrm{km}^{2}$. The proportion of the population employed in agriculture does not differ between LFA and TAL.

Areas affected by specific handicaps are characterised by lower soil fertility in comparison with areas outside LFA.

\section{Management of TAL within and outside of the Less Favoured Areas}

Comparison of TAL management intensity showed that $68 \%$ of TAL located outside the LFA are regularly managed and only $48 \%$ of TAL inside the LFA are regularly managed (Figs $4-6)$. On the other hand, abandonment occurs on $8 \%$ of TAL outside the LFA and $17 \%$ of TAL inside the LFA. The difference between those proportions are significant at $P<0.0001$. Therefore, we can reject our null hypothesis (the proportion of managed and abandoned TAL are same inside and outside the LFA) and conclude that management intensity of TAL inside LFA is 


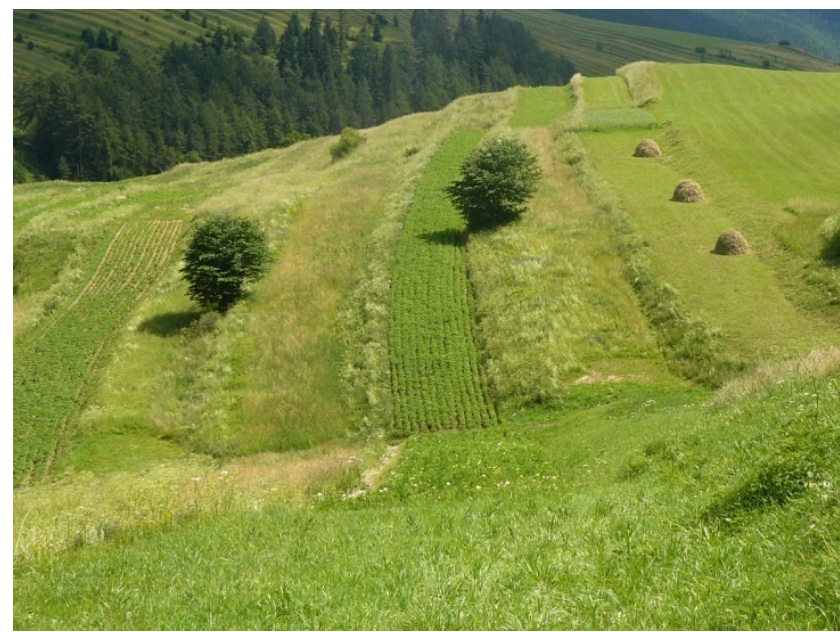

Fig. 5. Regularly managed plots TAL of Arable-Land and Grasslands (Liptovská Teplička, Spiš region, 2010, Photo: J. Špulerová)

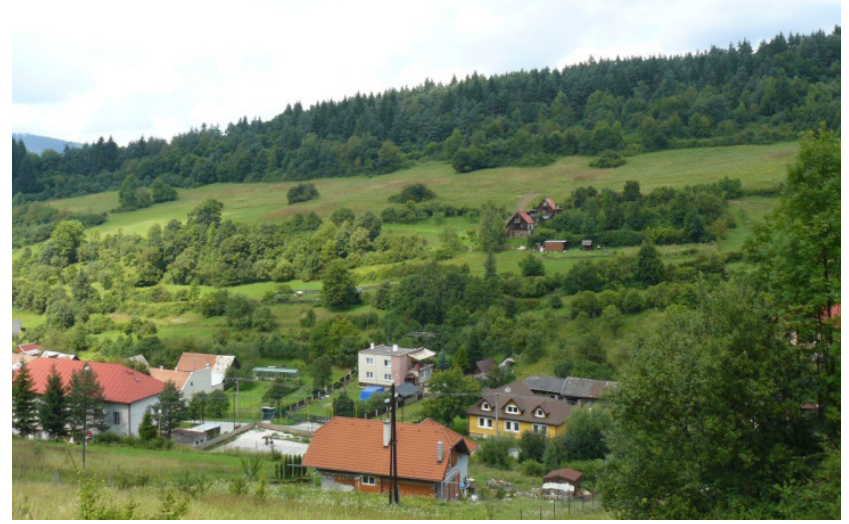

Fig. 6. Partly abandoned mosaic of TAL of Arable-Land, Grasslands and Orchards (Ráztoky, Považský region, 2011, Photo: J. Špulerová). significantly lower than management of TAL outside LFA. The LFA payments that should compensate for lower agricultural production in LFA do not mitigate the abandonment of TAL effectively. Because of the low number of TAL polygons located outside the LFA, we were not able to do this comparison separately for specific TAL types.

\section{Discussion}

Our correlation of TAL and LFA distribution confirmed our expectation that most of the TAL area would be situated in LFA. While the average cover of TAL within the LFA is 1.03 ha. $\mathrm{km}^{2}$, outside the LFA it is only 0.41 ha. $\mathrm{km}^{2}$. This is the legacy of agricultural collectivisation (in the second half of the 20th century), which transformed most of the TAL into largescale fields. Collectivisation predominately occurred in those areas most suitable for agricultural production (Lieskovský et al., 2014), so TAL located on less suitable areas (those now classified as LFA) were more likely to survive. One exception is TAL of Vineyards, which are naturally located in the warmer climates better suited for grape-growing (Falcao et al., 2010).

The CAP provides specific forms of support, integrated into the rural development programme, to businesses operating in LFA conditions. Even though sustainable land management has been one of the objectives of the CAP in LFA since the late 1980s, farms in LFA are still threatened by abandonment, as is apparent from our study. The results of our study 
indicated that LFA payments for TAL are not accomplishing their aims effectively, as the proportion of abandoned TAL plots inside the LFA areas is significantly higher than outside the LFA areas. Lower intensities of land use are often strongly influenced by higher slope, elevation, less productive soils, unfavourable conditions for agriculture and distance from nearby settlements (Druga, Faltan, 2014; Pazúr et al., 2014). Land abandonment in LFA is still an ongoing problem due to the handicap to farming, and has been caused by the globalisation of commodity markets and CAP reforms (van Zanten et al., 2014). Bezák and Halada (2010) identified other factors threatening to biodiversity of the agricultural landscape in the mountain regions, including: (I) intense pressure by owners and investors to convert agricultural land to construction land; (II) insufficient legislative support to protect the TAL; (III) a lack of publicity regarding TAL-related issues, and concomitant low awareness of TAL among the general public and state representatives; and (IV) insufficient research and monitoring of changes in the TAL; and others.

Our analyses of the natural conditions of TAL and their management intensity showed that TAL areas are situated mostly in those mountain regions where agricultural land abandonment is occurring more intensively. Abandonment and the resulting succession have been found to be the most significant threats to TAL and its biodiversity (Špulerová et al., 2014), as a consequence either of changed employment structure and decreased number of residents, or of intensification of agricultural use (Izakovičová et al., 2010). Most of the areas with the present TAL are situated in regions marginal from economic, demographic and social points of view, and the local inhabitants are not very keen on managing the agricultural landscape because of low yields from the land. Agricultural fields are managed mostly by older farmers; the younger generation is not very interested in traditional management. The older farmers do not have the financial and technical resources to be competitive with producers who practice intensive farming. Therefore inputs are higher than outputs, which make for an unsustainable situation for traditional farming (Bezák, Mitchley, 2014). Less serious, but still significant, threats arise from increasing tourism, urban development and reforestation. Tourism, with the associated construction of new cottages and resorts, provides a higher income for the local population than traditional management of agricultural conditions under difficult conditions.

Studies from the Czech Republic, Slovakia and Southern Europe have shown that farms in LFA depend heavily on subsidies to remain viable. Farm strategies have often been directed towards lowering labour inputs, lowering forage deficits through on-farm produced resources and acquiring subsidies (Jones et al., 2014; Štolbová, Molčanová, 2009).

More than half of the agribusinesses in the SR, which are legal persons, operate in less favoured conditions. The successful utilisation of the measure since joining the EU is indicated by the growing numbers of applicants for LFA payments. Ownership arrangements and integration into the Land Parcel Identification System have influenced the degree of land use very significantly (Štolbová, Molčanová, 2009). Evaluation of farming in the LFA conditions has concluded that legal persons and business companies achieve better results in almost all the indicators than agricultural cooperatives (Szabo, Grznar, 2013). On the other hand, these cooperatives get more subsidies, as CAP supports greater productivity and inhibits extensification (Donald et al., 2002). Questionnaire research on TAL management (Lieskovský et 
al., 2015) showed that the majority of small farmers did not meet the required criteria for receiving CAP support, as they are usually composed of small fields with specific physical condition. The current social capital system is very demanding when it comes to administrative tasks and the financial capital system is inaccessible for many rural farmers (Bezák, Mitchley, 2014).

As preservation of TAL depends mainly on individual small-scale farming and on eventual state subsidies, it must be asked if there is enough interest in stopping abandonment of these remnants of past ways of farming which double as havens of biological and structural diversity (Špulerová et al., 2014). TAL provides for society many other ecosystem services - for example, TAL with bounds contributes to water retention in the country, providing protection against flooding and erosion (Barančoková, Kenderessy, 2014; Skokanová, 2013). Farming in LFA should be continued in order to conserve or improve the environment, maintain the countryside and preserve the tourist potential of these culturally historically valuable areas. Businesses operating in the LFA conditions should be oriented towards the development and utilisation of rural resources via sustainable economic systems. Agricultural policy should aim to ensure adequate incomes and cost-effective farming for business entities operating under these conditions (Szabo, Grznar, 2013); these businesses should then be expected to concern themselves with environmental protection and maintenance of nature and settlement of a country. A production oriented, but multifunctional and environmentally friendly agriculture that maintains landscapes and biodiversity has also been advocated by stakeholders surveyed across the study areas around Europe (Baránková et al., 2011; Soliva et al., 2008).

\section{Conclusion}

Our analysis confirmed that most of the preserved TAL in Slovakia are situated in LFA, except TAL of vineyards. Abandonment of TAL inside LFA is significantly higher than outside the LFA. The LFA support does not mitigate the abandonment of TAL effectively. Even if more than half of agribusinesses in the SR operate in less favoured conditions, only a minor proportion of CAP subsidies are directed towards TAL management. Most of the TAL is managed by small-scale farmers who often lose interest in applying for CAP subsidies. CAP support requires complicated administrative work, which is not worth the effort for small farmers. If we want to preserve the TAL for the future, it is necessary to stop the existing negative trend of abandonment and search for new ways to motivate farmers to continue their traditional farming. LFA support was set up specifically for this purpose as one of the CAP tools. Up to now, this provision has mostly been of benefit to bigger agricultural companies; therefore, the application scheme for the allocation of subsidies should be simplified and adjusted for use by small farmers.

\section{Acknowledgements}

This contribution was prepared within the project 'Diversity of agricultural landscape and its ecosystem services'. Grant No. 2/0158/14 from the Ministry of Education of the Slovak Republic and the Slovak Academy of Sciences. We are thankful to James Asher for English revision. 


\section{References}

Barančoková, M. \& Kenderessy P. (2014). Assessment of landslide risk using GIS and statistical methods in Kysuce region. Ekológia (Bratislava), 33(1), 26-35. DOI: 10.2478/eko-2014-004.

Baránková, Z., Dobrovodská, M., Štefunková, D., Babicová, D., Moyzeová, M. \& Petrovič F. (2011). Participation of local people on identifying the landscape values and future development in historical agricultural landscapes. Ekológia (Bratislava), 30(2), 216-228. DOI: 10.4149/ekol_2011_02_216.

Bezák, P. \& Halada L. (2010). Sustainable management recommendations to reduce the loss of agricultural biodiversity in the mountain regions of NE Slovakia. Mt. Res. Dev., 30(3), 192-204. DOI: 10.1659/MRD-JOURNALD-10-00023.1.

Bezák, P. \& Mitchley J. (2014). Drivers of change in mountain farming in Slovakia: from socialist collectivisation to the Common Agricultural Policy. Reg. Environ. Change, 14(4), 1343-1356. DOI: 10.1007/s10113-013-0580-x.

Council Regulation (EC) (1999). No 1257/1999 of 17 May 1999 on support for rural development from the European Agricultural Guidance and Guarantee Fund (EAGGF) and amending and repealing certain Regulations.

Dankaninová, L. \& Gajdoš P. (2012). Epigeic spider communities in historical structures of agricultural landscape (vineyard landscape in the Svätý Jur area) (in Slovak). Folia Faunistica Slovaca, 17(3), 275-290.

Dax, T. (2005). The redefinition of Europe's Less Favoured Areas [WWW Document]. http://mpra.ub.uni-muenchen. de/711/ (accessed 12.12.14).

Dobrovodská, M. (2006). The development of relations between man and landscape in a historical mountain agricultural landscape of Slovakia. Ekológia (Bratislava), 25(1), 38-48.

Dobrovodská, M., Špulerová, J. \& Štefunková D. (2010). Survey of historical structures of agricultural landscape in Slovakia. In Living landscape: the European Landscape Convention in research perspective (pp. 88-92). Conference Materials, Vol. 2. 18-19 October, Florence.

Donald, P.F., Pisano, G., Rayment, M.D. \& Pain D.J. (2002). The common agricultural policy, EU enlargement and the conservation of Europe's farmland birds. Agr. Ecosyst. Environ., 89(3), 167-182. DOI: 10.1016/S01678809(01)00244-4.

Druga, M. \& Faltan V. (2014). Influences of environmental drivers on land cover structure and its long-term changes: A case study of the villages of Malachov and Podkonice in Slovakia. Moravian Geographical Reports, 22, 29-41. DOI: 10.2478/mgr-2014-0016.

Džatko, M. (2003). Sustainable land use in Slovakia. Agric. Conspec. Sci., 68, 9-12.

EU/EC 86/466/EEC-1986 council directive on concerning the community list of less-favoured farming areas within the meaning of directive 75/268/EEC amended by 91/465/EEC, 1986.

Falcao, L.D., Burin, V.M., Sidinei Chaves, E., Vieira, H.J., Brighenti, E., Rosier, J.-P. \& Bordignon-Luiz M.T. (2010). Vineyard altitude and mesoclimate influences on the phenology and maturation of Cabernet-Sauvignon grapes from Santa Catarina State. J. Int. Sci. Vigne Vin, 44(3), 135-150. www.jisvv.com

Izakovičová, Z., Moyzeová, M. \& Oszlányi J. (2010). Problems in agricultural landscape management arising from conflicts of interest - a study in the Trnava region, Slovak Republic. In H. Wiggering, H.-P. Ende, A. Knierim \& M. Pintar (Eds.), Innovations in European rural landscapes (pp. 77-95). Heidelberg, Dordrecht, London, New York: Springer.

Jones, N., de Graaff, J., Duarte, F., Rodrigo, I. \& Poortinga A. (2014). Farming systems in two less favoured areas in Portugal: Their development from 1989 to 2009 and the implications for sustainable land management. Land Degrad. Dev., 25(1), 29-44. DOI: 10.1002/ldr.2257.

Lieskovský, J., Kenderessy, P., Špulerová, J., Lieskovský, T., Koleda, P., Kienast, F. \& Gimmi U. (2014). Factors affecting the persistence of traditional agricultural landscapes in Slovakia during the collectivization of agriculture. Landsc. Ecol., 29(5), 867-877. DOI: 10.1007/s10980-014-0023-1.

Lieskovský, J., Bezák, P., Špulerová, J., Lieskovský, T., Koleda, P., Dobrovodská, M., Bürgi, M. \& Gimmi U. (2015). The abandonment of traditional agricultural landscape in Slovakia - Analysis of extent and driving forces. J. Rural Stud., 37, 75-84. DOI: 10.1016/j.jrurstud.2014.12.007.

Machová, I. \& Kubát K. (2014). The species composition on agricultural terraces in NW part of Slovakia. Ekológia (Bratislava), 33(4), 307-320. DOI: 10.2478/eko-2014-0029.

Ministry of Agriculture (2008). Methodological Guideline of the MA SR No. 2047/2010-620 to SR Government Decree No. 499/2008 Coll. on the conditions for granting aid under the rural development program, as amended by SR Government Regulation No. 121/2009 Coll., as amended by SR Government Regulation No. 128/2010 Coll. 
Ministry of Agriculture (2009). Rural Development Program of Slovakia for 2007-2013 (Program rozvoja vidieka SR 2007-2013, SLOVENSKO).

Mojses, M. \& Petrovič F. (2013). Land use changes of historical structures in the agricultural landscape at the local level - Hriňová case study. Ekológia (Bratislava), 32(1), 1-12. DOI: 10.2478/eko-2013-0001.

Pazúr, R., Lieskovský, J., Feranec, J. \& Otahel' J. (2014). Spatial determinants of abandonment of large-scale arable lands and managed grasslands in Slovakia during the periods of post-socialist transition and European Union accession. Appl. Geogr., 54, 118-128. DOI: 10.1016/j.apgeog.2014.07.014.

Pender, J.L. \& Hazell P.B.R. (Ed.) (2000). Promoting sustainable development in less-favored areas. International Food Policy Research Institute (IFPRI).

Ruben, R. \& Pender J. (2004). Rural diversity and heterogeneity in less-favoured areas: the quest for policy targeting. Food Policy, 29(4), 303-320. DOI: 10.1016/j.foodpol.2004.07.004.

Rudow, K. (2014). Less Favoured Area payments - impacts on the environment, a German perspective. Agr. Econ., 60(6), 260-272.

Skokanová, H. (2013). Can we combine structural functionality and landscape services assessments in order to estimate the impact of landscape structure on landscape services? Moravian Geographical Reports, 21(4), 2-14. DOI: $10.2478 /$ mgr-2013-0016.

Slámová, M., Jančura, P. \& Daniš D. (2013). Methods of historical landscape structures identification and implementation into landscape studies. Ekológia (Bratislava), 32(3), 267-276. DOI: 10.2478/eko-2013-0023.

Soliva, R., Rønningen, K., Bella, I., Bezák, P., Cooper, T., Flø, B.E., Marty, P. \& Potter C. (2008). Envisioning upland futures: Stakeholder responses to scenarios for Europe's mountain landscapes. J. Rural Stud., 24(1), 56-71. DOI: 10.1016/j.jrurstud.2007.04.001

Szabo, L. \& Grznar M. (2013). Farms in the less favoured area conditions in Slovakia. Agr. Econ., 59(12), 543-550.

Špulerová, J., Dobrovodská, M., Lieskovský, J., Bača, A., Halabuk, A., Kohút, F., Mojses, M., Kenderessy, P., Piscová, V., Barančok, P., Gerhátová, K., Krajčí, J. \& Boltižiar M. (2011). Inventory and classification of historical structures of the agricultural landscape in Slovakia. Ekológia (Bratislava), 30(2), 157-170. DOI: 10.4149/ ekol_2011_02_157.

Špulerová, J., Dobrovodská, M., Štefunková, D., Bača, A. \& Lieskovský J. (2014). Biodiversity of traditional agricultural landscapes in Slovakia and their threats. In S.-K. Hong, J. Bogaert \& Q. Min (Eds.), Biocultural landscapes (pp. 113-128). Dordrecht: Springer. DOI: 10.1007/978-94-017-8941-7_9.

Štolbová, M. \& Molčanová J. (2009). Evaluation of support for farms in less-favoured areas in the Czech Republic and Slovakia. In J. Neuwirth \& K. Wagner (Eds.), Rural areas and development (pp. 285-301). European Rural Development Network Studies. http://purl.umn.edu/157619.

van Zanten, B.T., Verburg, P.H., Espinosa, M., Gomez-y-Paloma, S., Galimberti, G., KantelhardT, J., Kapfer, M., Lefebvre, M., Manrique, R., Piorr, A., Raggi, M., Schaller, L., Targetti, S., Zasada, I. \& Viaggi D. (2014). European agricultural landscapes, common agricultural policy and ecosystem services: a review. Agron. Sustain. Dev., 34(2), 309-325. DOI: 10.1007/s13593-013-0183-4. 